\title{
Syringe Functionality Testing
}

National Cancer Institute

\section{Source}

National Cancer Institute. Syringe Functionality Testing. NCI Thesaurus. Code C134113.

Testing a syringe to verify it functions properly. 